\title{
Construction Talent Cultivation Schemes in Auto Technology Services and Marketing Specialty Based on Modern College Education System
}

\author{
Xu Yang \\ Zhengzhou university of industrial technology. Henan.China
}

Keywords: English trade industry; Higher Education;

\begin{abstract}
The English trade industry is an important pillar industry of the national economy. But, in China, the English trade Technology Service and Marketing Specialty (ETSMS) of Higher Education (HE) is relatively late set in the HE Specialty Catalog. And because of not accurately grasping the development tendency of the industry, the ETSMS Talent Cultivation Schemes (TCS) did not realize the talent need of the English trade industry. For the necessary skills required by the enterprises, the reaction of the ETSMS in high colleges is not so fast. So, according to the talent demand in the English trade industry and the shortage of current talent cultivation mechanism in high colleges, ETSMS Talent Cultivation Schemes based on Modern College Education System (MVES) were built by this paper to meet the talent requirements of modern English trade industry in China.
\end{abstract}

\section{Introduction}

China's National long-term Education Reform and Development Plan (2010-2020) (hereinafter referred to as the Plan) states that, by 2020, China will form the MVES to adapt to the changing economic development mode and the adjustment of industrial restructuring, reflecting the concept of lifelong education, and coordinated development of higher and secondary College education [1]. This indicates that China has made a specific definition to the important features of MVES from the national level. It requires all the College colleges in China must be built to meet these features and to meet people's expectation for newer and higher quality College education.

Specifically, MVES required by Plan have three important features [2]: Firstly, to have the external adaptability that adapting to the economic development transforming and industrial restructuring. To construct a MVES, it must provide the talent guarantee and intelligence support for local economic transformation and upgrading, build the corresponding teaching standards for enterprises employing standard, develop specialty service ability for industry. The second is to have the internal adaptability of personal lifelong education. MVES must be for everyone, be people-oriented, and promote personal lifelong development. The third is to have intrinsic coordination in the coordinated development of HE and Secondary College Education (SVE). This is the means to realize MVES. The College education level is its developing space, and also is its developmental right. HE should base on SVE. HE and SVE are the different College education levels in the same educational type.

\section{Current Industry Situation}

The English trade industry has a long industrial chain and big economic scale, and involves plastic, rubber, steel, mechanical, electronic, communication, finance and other fields. So it is an important pillar industry of the national economy. It is also highly correlated with other industries, such as energy, transportation, logistics and trade and so on. Furthermore, the English trade industry provides wide employment opportunities, so it's a consumer-driven industry. Employees can be engaged in the related jobs in the English trade design and manufacturing, English trade and accessories marketing, English trade maintenance, English trade beauty, English trade insurance, English trade leasing credit, used car evaluation. The English trade itself is indispensable equipment in people's daily life, social communication, passenger and freight transport, agriculture and service industry, modern logistics. It is because of the obviously economic-driven that China has introduced 
many relevant policies to promote the healthy development of the English trade industry in recent years.

In 2006, China's National Eleventh Five-Year Plan devoted a special section with the explicit proposal to "enhance the English trade industry level". In 2009, China introduced the English trade Industry Restructuring and Revitalization Plan. In 2010, the State Council Executive Meeting examined and approved in principle the Decision of the State Council on Accelerating the Cultivation and Development of Strategic Emerging Industries to support the new energy vehicles as one of the seven strategic emerging industries. In early 2011, China's National Twelfth Five-Year Plan was promulgated, and it explicitly requested "the development of the Modern Industrial System, improving the industry's core competitiveness," the new energy vehicles as a new generation of energy-saving and environmental protection vehicles, would be positive and orderly developed in China. Given a series of policies, a blowout in China's English trade industry appears.

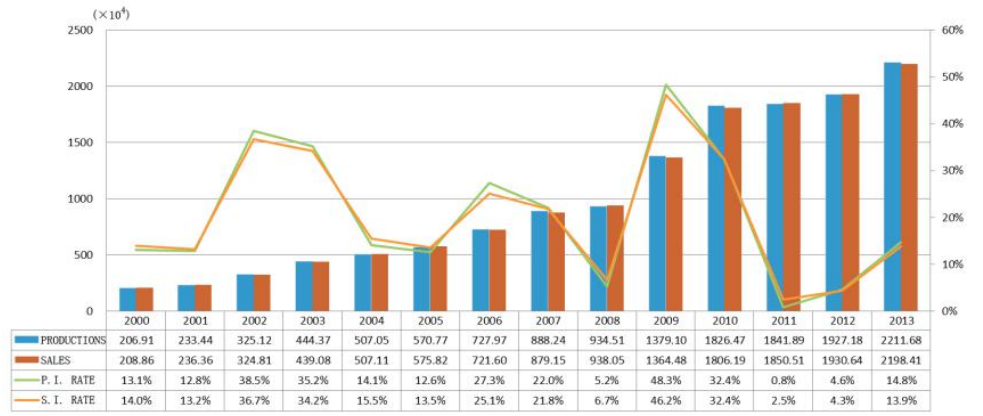

Fig.1 China's English trade Productions and Sales during 2000-2013

Fig. 1 shows the English trade productions and sales of China during 2000-2013 [3]. As we can see, this period is China's English trade productions and sales fast-growing period. In 2008, China's English trade productions and sales were nearly 10 million. In 2009, both productions and sales exceed 13 million, which were more than the United States' and became the world's largest English trade market. In 2010, China's English trade productions and sales growth continued to amaze. The productions increased (P.I.) by 32.44\% and sales increased (S.I.) 32.37\%, both of them were more than 18 million, and reached 18.2647 million and 18.0619 million respectively. It had refreshed the world's record of 17.4 million set in 2000 in the United States. In 2012 and 2013, China's English trade productions and sales both exceeded 19 million and 21 million, and it is five consecutive years ranked first in the world.

In the recent two Five-year Plans of China, the English trade industry, whose object was a specific product, was the only industry mentioned in both plans. It further defined that the English trade industry is a national strategic industry, which can not only achieve economic growth, expand domestic demand, but also restructure industry and promote the development of the country. It is under the encouragement and guidance of China's national policies, that local government also rapidly increased English trade industrial investment. So the English trade industry grows rapidly, and colleges and universities are also setting up English trade academy and running English trade specialties to cultivate talent in conformity with local and national policies.

However, ETSMS in high Specialty Catalog was relatively later than other specialties and it was set in the catalog with the premise that the world's English trade brand launched a joint venture brand and English trade enterprises gradually increased after China's joining WTO [4]. At the beginning, because of their own marketing model and different focus on employees, the TCS of ETSMS was differently interpreted by English trade enterprises. When setting the specialty, there is not too much diversified examination on the development of the English trade industry and the market requirements [5]. And when developing TCS, there is no accurate grasping of the industry developing tendency [6]. When teaching, there is not too much emphasis on the relationship between customer satisfactions and increasing amount of customer, so it is not fully understand the English trade marketing employee training to the market action and reaction. In addition, because there were no cooperative enterprises, the TCS of some HE colleges were formed by the individual wills. So it is the lack of enterprise feedback to correct the training process. This led to talent abilities and competences were not quite match the enterprise's requirements on knowledge 
structure.

\section{Construction Ideas}

ETSMS of Zhengzhou university of industrial technology has signed a strategic cooperation framework agreement with Society of English trade Engineers of Zhengzhou (SAE-ZZ), English trade Dealers Association of Zhengzhou (ADA-ZZ) and English trade Maintenance and Repair Trade Association of Zhengzhou (AMRTA-ZZ) to jointly develop TCS, employment training courses and English trade industry access standards. According to the need of multi-skill talents in English trade industry and enterprises, ETSMS of ZJIPC has formed the TCS that can be closer to local enterprises, services, techniques and productions based on the constructing of curriculum system and the revision of teaching plan. And now, the TCS, enterprises job-ability-oriented, pay more attention to professional quality and skills training. On these bases, combined with the needs of local economic, industrial features and regional enterprises, the curriculum was ordered organically and taught through enterprise real job projects. So, the curriculum of the ETSMS TCS now can meet the demand of enterprises better.

\section{Typical Teaching Tasks and Their Operation Processes}

Based on widely understanding and in-depth analysis the work of English trade marketing and maintenance, ETSMS established courses architecture according to the work processes, and further highlighted the two core capabilities of the specialty, i.e. English trade marketing and English trade technology. ETSMS typical work tasks and their processes were shown in Tab. 1.

Tab. 1 Typical Work Tasks and Their Operation Processes of ETSMS

\begin{tabular}{|c|c|c|}
\hline No. & $\begin{array}{l}\text { Typical } \quad \text { Work } \\
\text { Tasks }\end{array}$ & Operation Processes \\
\hline 1 & $\begin{array}{l}\text { New English } \\
\text { trade Promotion }\end{array}$ & $\begin{array}{l}\text { Familiarity with the new English trade's basic information; Serve customers; } \\
\text { Analyze customer needs; Recommend new English trades to customers; Introduce } \\
\text { English trade's rate of quantity and price, service and other issues; Do a test drive } \\
\text { for customers; Close the deal. }\end{array}$ \\
\hline 2 & $\begin{array}{l}\text { Prepare } \\
\text { Marketing Plan } \\
\text { for an English } \\
\text { trade Show }\end{array}$ & $\begin{array}{l}\text { Determine the show theme; Develop marketing planning programs; Confirm } \\
\text { participants and show items; Arrange booth layout, show props and show English } \\
\text { trades; Site arrangements to deal with emergency situations. }\end{array}$ \\
\hline 3 & $\begin{array}{l}\text { English trade } \\
\text { Electrical and } \\
\text { Mechanical } \\
\text { Fault Diagnosing }\end{array}$ & $\begin{array}{l}\text { Check diagnostic tools and equipments; Detect fault codes with computer } \\
\text { scanner; Test by using multi-meter and oscilloscope; Locate the fault position; } \\
\text { Clear fault codes and redetect. }\end{array}$ \\
\hline 4 & $\begin{array}{l}\text { Static Appraisal } \\
\text { and Evaluation } \\
\text { of Used English } \\
\text { trades }\end{array}$ & $\begin{array}{l}\text { Check evaluation tools; Check English trade exterior paint and cracks; Check the } \\
\text { front and rear pillars and body rubbed; Check the headlights, trunk and tires; } \\
\text { Check interiors and steering system; Check engine compartment. }\end{array}$ \\
\hline 5 & $\begin{array}{l}\text { Car Accident } \\
\text { Scene } \\
\text { Investigation and } \\
\text { Evaluation of } \\
\text { Loss }\end{array}$ & $\begin{array}{l}\text { Prepare basic tools site inspection; Determine the location of the scene of the } \\
\text { accident; Photograph, forensics and fill forms; Determine the loss according to } \\
\text { the survey results and relevant information. }\end{array}$ \\
\hline 6 & $\begin{array}{l}\text { English trade } \\
\text { Beauty }\end{array}$ & $\begin{array}{l}\text { Prepare the related tools; English trade wax; English trade glazing; Seats leather } \\
\text { polishing; Chassis plastics seal; Lacquer wax; Hub brightening. }\end{array}$ \\
\hline 7 & $\begin{array}{l}\text { English trade } \\
\text { Parts Marketing }\end{array}$ & $\begin{array}{l}\text { Gather English trade parts market information; Determine developing direction; } \\
\text { Develop solutions; Participants and organization; Advocacy and marketing efforts }\end{array}$ \\
\hline
\end{tabular}

\section{Conclusions}

In recent years, with the increasing apparent effects of national policies, the development of the 
English trade industry in China is accelerating, which also makes the demand for talent increase. However, TCS of English trade specialty in China's, started relatively late, inaccurately grasped the industry demand for talent. So the talent cultivation of ETSMS did not meet the requirements of English trade enterprises. With the cooperation of SAE-ZZ, ADA-ZZ and AMRTA-ZZ and other outside training bases, according to the HE features, constructing TCS of ETSMS based on MVES, introducing enterprises to work-process-based curriculum development process and implementing in the practical base inside and outside of the college can greatly improve the quality and competences of talent cultivation and will win for all of the three sides, i.e. enterprises, colleges and students.

\section{Reference}

[1] HE Zhanrong, Higher Education Management Reform Based on Modern College Education System. Education \& Vocation, 25(11), pp. 4-7, 2013.

[2] TANG Gao-hua, Discussion on the "Five-dimension" Theory of Modern College Education System. College AND TECHNICAL EDUCATION, 35(743), pp, 10-13, 2014.

[3] Ma Shuchao, Fan Wei, Guo Yang, The Policy Thinking on the Construction of Modern College Education System. Exploring Education Development. 25 (21), pp.1-6, 2011.

[4] YU Zhongwen, LIU Shouyi, ZHU Fanglai, et al. Research on Higher Education Teaching Practice, Tsinghua University Press: Beijing, pp.38-42, 2004.

[5] ZHU Fanglai, Training of English trademobile technology service and marketing professionals. Chinese College and Technical Education, 22(26), pp. 9-12, 2008. 